Coordinate compounding in English and Spanish

\title{
Coordinate compounding in English and Spanish
}

\author{
Vincent Renner
}

Centre de Recherche en Terminologie et Traduction

Université Lumière Lyon 2

86 rue Pasteur

69007 Lyon

France

vincent.renner@univ-lyon2.fr

Jesús Fernández-Domínguez

Departamento de Filología Española

Universidad de Jaén

Paraje "Las Lagunillas" s/n

23071 Jaén

Spain

jesusferdom@gmail.com 


\title{
Coordinate compounding in English and Spanish
}

\begin{abstract}
Coordinate compounding is a process which has been only sporadically considered in wordformation studies on Germanic and Romance languages. In this paper, we compare the situation in English with that in Spanish as far as formal structure and semantics are concerned. To this end, an operational definition of coordinate compounding is first provided, after which a semantic classification of coordinate compounds is developed. For each type, variants are discussed, representative examples are provided, and similarities and dissimilarities between the two languages are highlighted. We finish by raising the issues of recursiveness and productivity in coordinate compounding and we examine the possibilities of expansion and profitability of the different patterns. Our analysis reveals marked similarities between English and Spanish coordinate compounding at various levels, hinting at the possible existence of a cross-linguistic set of common core features in the class of coordinate compounds in both Germanic and Romance.
\end{abstract}

Keywords: word-formation; compounding; coordination; English; Spanish. 


\section{Introduction}

Romance languages are said to resort to the word-formation process of compounding to a much lesser extent than Germanic languages. This is commonly illustrated by the fact that many Germanic compounds correspond to simplex or derived lexemes in Romance (see e.g. Paillard 2000: 55-56 for French vs. English); examples of this contrast in Spanish and English are gallina $\sim$ gallinero / hen $\sim$ henhouse and plátano $\sim$ platanal / banana $\sim$ banana plantation. Coordinate compounds represent only a small fraction of the whole class of compounds in both the Romance and Germanic families. Guevara and Scalise (2009)'s approximations are respectively 16 and 12 percent, and more conservative estimates, which rely on random samples of dictionary-listed compounds, put the percentage as low as about 2 percent for English (Arnaud 2002: 4; Berg 2009: 134). The subclass of Spanish coordinate compounds being relatively small, it has unsurprisingly received somewhat scant attention from word-formationists, and in this article we endeavour to repair this neglect, to delve into the formal and semantic details of these constructions and to compare the situation in Spanish with that in English, a language for which fine-grained analyses of coordinate compounding are already available (e.g. Renner 2008; Bauer 2010).

The general structure of the article is as follows. We first present a definition of coordinate compounding and associate it with a unitary metalinguistic test sentence (Section 2), and we then attempt a semantic characterization of coordinate compounds based on their lexical input structure, i.e. noun-noun, adjective-adjective, verb-verb and adverb-adverb units (Section 3). For each subtype, several illustrative examples are presented, the English and Spanish variants are contrasted, and the most prominent features are pointed out. In Section 4, we focus on the issues of productivity and recursiveness to evaluate the creative potential of this word-formation device. 


\section{Definition of coordinate compounding}

There has been a recent surge of cross-linguistic interest in coordinate compounding, which has led to a multiplication of classificatory and terminological discordances in the literature (for a discussion, see Wälchli 2005; Bauer 2008; Renner 2008; Arcodia 2010), and one should be aware that various authors may use the same terms, e.g. dvandva or co-compound, to refer to different types of compounds. In this study, the stance adopted is to use terms which are as transparent as possible and which closely reflect the semantics of each type and subtype.

The operational definition of coordinate compounds proffered in this research is the following: those units composed of co-hyponymous lexemes for which the linear order of elements is deemed to be grammatically irrelevant (the factors coming into play are phonological and pragmatic). In some cases, the two variants $\mathrm{X}+\mathrm{Y}$ and $\mathrm{Y}+\mathrm{X}$ have been institutionalized (e.g. Eng. lease-lend / lendlease; Sp. oxidación-reducción / reducción-oxidación), ${ }^{1}$ which leads us to claim that membership in the category of coordinate compounds can be materialized through a unitary metalinguistic test sentence, " $\mathrm{X}+\mathrm{Y}$ could be named $\mathrm{Y}+\mathrm{X}$ " for English and "X+Y podría decirse $\mathrm{Y}+\mathrm{X}$ " for Spanish, as in the following examples:

i. nouns

- Fighter-bomber could be named bomber-fighter.

- *Cherry tomato could be named tomato cherry.

- Caza-bombardero ${ }^{2}$ podría decirse bombardero-caza.

- *Mono araña ${ }^{3}$ podría decirse araña mono.

\footnotetext{
${ }^{1}$ 'oxidation + reduction'.

2 'fighter + bomber'.

${ }^{3}$ 'monkey + spider $=$ spider monkey'.
} 
ii. adjectives

- Blue-green could be named green-blue.

- $\quad$ Icy-cold could be named cold-icy.

- Obsesivo-compulsivo ${ }^{4}$ podría decirse compulsivo-obsesivo.

- *Jurídico-laboral ${ }^{5}$ podría decirse laboral-jurídico.

iii. verbs

- Work-study could be named study-work.

- *Blow-dry could be named dry-blow.

- Duermevela ${ }^{6}$ podría decirse veladuerme. ${ }^{7}$

Some compounds fail to pass the above test because of their directional semantics. This is the case of asynchronous compounds such as homicide-suicide, drag-drop, servicio-volea ('serve + volley') and copia-pega ('copy + paste'), which refer to events or actions which are consecutive in time, and also that of units such as English-Russian or español-francés ('Spanish + French') - dubbed "translative" by Bauer (2001: 700) - when modifying nouns such as dictionary, glossary, manual / diccionario, glosario, manual. The two elements being on an equal footing semantically (neither can be said to be the sole head of the compound), the non-subordinate nature of such compounds is, however, unambiguous.

${ }^{4}$ 'obsessive + compulsive'.

${ }^{5}$ 'legal + labor $($ adj. $)=$ pertaining to labor law'.

${ }^{6}$ 'sleep + be awake = state intermediate between sleeping and being awake'.

${ }^{7}$ To the best of our knowledge, there is no such thing as subordinate verb-verb compounding in Spanish. 


\section{Semantic typology}

In this section, we propose a semantic typology of coordinate compounds making use of test sentences. Most - but not all - types are attested in the two languages; Spanish most notably contrasts with English by exhibiting a somewhat richer semantic typology of verb-verb compounding.

\section{1. noun-noun compounds}

Three semantic classes of noun-noun compounds are identified:

i. multifunctional compounds such as owner-operator, speaker-hearer, gymnasiumauditorium / compositor-arreglista ('composer + arranger'), lavadora-secadora ('washer + dryer'), sofá-cama ('sofa + bed'), which can be felicitously inserted in the test sentence "An $X+Y$ is an $X$ who/which is also a $Y "$ / "Un(a) $X+Y$ es un(a) X que también es un(a) $Y "$;

ii. hybrid compounds such as troutperch, mashie-niblick, nickel-iron, folk punk / aguanieve $($ 'rain + snow $=$ sleet' $)$, gomorresina $($ 'gum + resin' $)$, cerapez $(' w a x+$ pitch' $)$, pasitrote ${ }^{8}($ 'walk + trot $=$ ambling movement'), which can be felicitously inserted in the test sentence " $X+Y$ is a blend of $X$ and $Y "$ / "X+Y es una mezcla de Xy de $Y "$;

iii. additional compounds such as robbery-homicide, space-time, tractor-trailer, Luke-Acts ${ }^{9}$ / compraventa ('buying + selling'), aguaviento ('rain + wind'), casatienda ('house + store'),

${ }^{8}$ The vowels $i$ and $o$ are occasionally used compound-internally in Spanish (e.g. capisayo $<$ capa + sayo $[$ 'cloak + smock $=$ bishop's mantelletta']; ceromiel $<$ cera + miel $[$ 'wax + honey $=$ mixture of wax and honey']). We indicate the presence of such compound markers (for a broad discussion of the concept, see Ralli 2008) through underlining.

${ }^{9}$ In Biblical studies, Luke-Acts refers to the hypothetical composite work of the Gospel of Luke and the Acts of the Apostles in the New Testament. 
tarde-noche ('evening + night'), which can be felicitously inserted in the test sentence "An $X+Y$ is an $X$ plus a $Y " / " U n(a) X+Y$ es la suma de un(a) Xy de un(a) $Y "$.

Multifunctionals and hybrids have a strong affinity - they share the property of being constituted of elements whose denotata are perceptually merged and are, in this respect, unlike additionals, whose denotata are simply juxtaposed -, but we have chosen to distinguish the two classes due to the clear difference in acceptation between the test sentences. In Spanish, there is a formal dissonance between multifunctionals, which never seem to admit a medial compound marker, and hybrids, which include constructions with a marker (e.g. pasitrote, ceromiel, gomorresina), which also goes against the idea of merging the two categories.

In the two languages, exocentric compounds are attested only in the class of additionals: in English, a penny-farthing, also known as an ordinary, is a bicycle with a very large ("penny-like") front wheel and a small ("farthing-like") rear wheel; in Spanish, capigorra ('cloak + cap') denotes an idle vagrant through two conceptually salient sartorial details and ajoqueso ('garlic + cheese') refers to a dish prepared with garlic and cheese, but also onion and pepper.

\section{2. adjective-adjective compounds}

Two semantic classes of adjective-adjective compounds are identified:

i. additional compounds such as deaf-blind, manic-depressive, pale-dry, solar-lunar, sweetsour / agripicante ('sour + spicy'), anchicorto ('wide + short'), fisicoquímico ('physical +

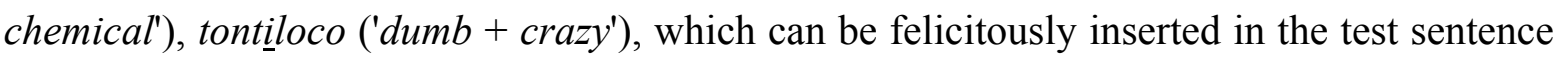
"To be $X+Y$ is to be $X$ and to be $Y "$ / "Ser $X+Y$ es ser $X y$ ser $Y "$;

ii. hybrid compounds such as blue-red (= purplish), medium-rare, dressy-casual / verdiazul $($ 'green + blue'), verdiseco ('green $+d r y=h a l f-d r y ')$, which can be felicitously inserted in the test sentence "To be $X+Y$ is to be about midway between $X$ and $Y "$ / "Ser $X+Y$ es estar a 
medio camino entre $X$ e $Y^{\prime \prime}$.

Exocentric adjective-adjective compounding is attested only in the case of Spanish, in claroscuro

$($ 'light + dark $=$ chiaroscuro').

\section{3. verb-verb compounds}

Five semantic classes of verb-verb compounds are identified, the last two being restricted to Spanish:

i. synchronous compounds, which fit the test sentence "X+Y refers to the concept of 'Xing and Ying at the same time"" / "X+Y se refiere al concepto de 'X e Y al mismo tiempo"', as in work-study / ganapierde ('win + lose = game of loser-takes-all');

ii. asynchronous compounds, which fit the test sentence "X+Y refers to the concept of 'Xing and then Ying"' / "X+Y se refiere al concepto de 'Xy luego $Y^{\prime \prime \prime}$, as in copy-paste, stop-start, fly-drive / corta-pega $($ 'cut + paste $=$ cut-paste operation'), quitapón ('remove + put $=$ headstall ornament for mules');

iii. disjunctive compounds, which fit the test sentence " $\mathrm{X}+\mathrm{Y}$ refers to the concept of 'Xing or Ying"' / "X+Y se refiere al concepto de 'Xo Y"', as in pass-fail / arrancasiega ('uproot + cut = process of uprooting or cutting');

iv. reduplicative-intensive compounds, in which $\mathrm{X}$ is formally equivalent to $\mathrm{Y}$, and whose semantics are "To X a lot" / "X mucho"; to the best of our knowledge, English has no such thing as reduplicative-intensive verb-verb compounding; ${ }^{10}$ Spanish has bullebulle ('boil +

\footnotetext{
${ }^{10}$ The adjectival compound win-win arises from the juxtaposition of two identical verb forms, but its semantics are not reduplicative-intensive; it belongs among synchronous compounds.
} 
boil $=$ busybody') and picapica ('itch + itch $=$ itching powder');

v. hybrid compounds, which fit the test sentence "X+Y refers to a state/process which is about midway between Xing and Ying" / "X+Y se refiere a un estado/proceso que está a medio camino entre $X$ e $Y^{\prime \prime}$; to the best of our knowledge, English has no such thing as hybrid verbverb compounding; Spanish has duermevela ('sleep + be awake = state intermediate between sleeping and being awake').

The semantics of some verb-verb compounds are not beyond debate among morphologists and lexicographers. This is for example the case of arrancasiega in Spanish, Bustos Gisbert (1986: 318) and Alvar Ezquerra (1993: 23) considering that it has a hybrid reading, and the editors of the Diccionario de la lengua española a disjunctive one, or that of freeze-dry in English, Renner (2006: 59-62) and the editors of the American Heritage dictionary of the English language considering that the compound is a troponym of preserve, and therefore a coordinate compound, and Bauer (2010: 204 ) and the editors of the Oxford English Dictionary (= OED) considering it is a troponym of $d r y$, and hence a subordinate compound. ${ }^{11}$ Verb-verb compounds also markedly differ in the two languages in so far as Spanish accepts only exocentric nominal outputs whereas English accepts verbal, adjectival and nominal ones (respective examples are scrunch-dry, cook-chill and lendlease).

\section{4. adverb-adverb compounds}

Adverb-adverb compounding is highly marginal in English, and it is unattested in Spanish. The

\footnotetext{
${ }^{11}$ Troponymy is an asymmetrical relation of sense between two verbs. This relation is explained in terms of manner elaboration, as in the formula "To run is to move in some manner", where run is said to be a troponym of move (for a discussion, see Fellbaum 2002).
} 
only unequivocal English example is softly-softly, an exocentric reduplicative compound with an adjectival output. Willy-nilly is an adverb and it could be argued that there is a coordinate relation between the two elements - the OED gives nilly-willy as an established variant -, but the construction is not a compound in the narrow sense of the term, as nilly is not an English lexeme. It is rather a pseudo-compound, which has arisen through univerbation (< "will $I$, nill $\left.I^{\prime \prime}\right)$. Similarly, following Cook (1969: 135), Jackson and Zé Amvela (2000: 83) list in-to and through-out as instances of coordinate adverbial compounding, but this classification is, in our view, strongly objectionable as the first example is not known to be an adverb, and the second one does not fit the definition given in Section 2 - the OED gives out-through as an obsolete, chiefly Scottish variant of throughout, but linear reversibility is synchronically impossible.

\section{Productivity and recursiveness}

English and Spanish compounds are said to differ widely in their general proclivity to both productivity, which can be broadly defined as the property whereby a word-formation process has the potential for the rule-governed creation of an indefinite number of words, and recursiveness, which refers to the possibility of lengthening a compound by using it as the base in a new compounding operation. This is true in the general case, i.e. that of subordinate compounds, but the situation is more complex and strikingly similar in the two languages as far as coordinate compounding is concerned. The relative productivity of the types listed in the previous section is as follows:

- a high degree of productivity for multifunctional nouns, and also for some classes of additional adjectives - mainly neoclassical compounds, e.g. oronasal, Franco-British, hispano-inglés ('Hispano-English'), but also colour adjectives such as blanquinegro ('white 
+ black'), azuliverde ('blue + green') and grisirirojo ('grey + red') in Spanish; ${ }^{12}$

- a low degree of productivity for hybrid and additional nouns;

- a near-zero degree of productivity for verb-verb compounds and hybrid adjectives.

We would like to posit as a general principle that the degree of recursiveness of a given coordinate compounding pattern is correlated to the degree of productivity of that same pattern, which would explain why the distribution of recursive types runs parallel to that of productive types:

- relatively frequent recursiveness for multifunctional nouns - e.g. singer-composer-pianist / actor-bailarín-mimo ('actor + dancer + mime') - and some classes of additional adjectives e.g. orofaciodigital, Anglo-Franco-Spanish, blue-white-red / esternocleidomastoideo ('sternocleidomastoid'), anglo-germano-holandés ('Anglo-Germano-Dutch'), rojịblanquíazul $($ 'red + white + blue' $)$; $^{13}$

- infrequent recursiveness for hybrid and additional nouns; rare examples are rejectionembrace-elevation, north-northwest / caza-pesca-recolección ('hunting + fishing + gathering'), sur-sureste ('south-southeast') ${ }^{14}$

- absence of recursiveness for verb-verb compounds and hybrid adjectives.

12 The attestation of the last two adjectives goes against Val Álvaro (1999: 4813)'s contention that compounds with a medial marker cannot contain a final-stressed and consonant-final left element such as azul- ('blue') or gris- ('grey').

${ }^{13}$ Several triple units with a double -i- compound marker (e.g. rojịnegriblanco ['red + black + white'], blanquirojiviverde ['white + red + green']) are attested in Spanish, which disproves Rainer and Varela (1992: 139-140)'s claim that such formations are absent in the language.

\footnotetext{
${ }^{14}$ North-northwest and sur-sureste are exceptional examples of hierarchical (right-branching) coordinate compounding.
} 
In the case of multifunctionals and additional adjectives, longer units, like the following quadruplets, are also attested: singer-songwriter-producer-arranger, mother/father/nurturer /provider, Anglo-Franco-Turco-Russian / actor-director-escritor-estrella ('actor + director + writer + star'), marxista-leninista-estalinista-maoísta ('Marxist + Leninist + Stalinist + Maoist'), socioeconómico-político-cultural ('socio-economico-politico-cultural').

One substantial difference between subordinate and coordinate compounds lies in the relative ease of their semantic interpretation. Recursiveness in subordinate compounds gives rise to long units which may prove difficult to interpret, e.g. Berg (2006: 198)'s six-noun nonce compound child language acquisition research group member. Our claim is that this is not the case to the same extent with coordinate compounds because their internal structure and semantics remain relatively transparent as long as all the members of the compound are obvious co-hyponyms, as in the case of, for example, singer/composer/pianist/organist or actor-bailarín-mimo.

\section{Conclusion}

This study has brought to the fore the fact that English and Spanish coordinate compounds display striking similarities: a vast majority of the different lexical and semantic types are attested in both English and Spanish, and the relative proclivity to productivity and recursiveness of these types is remarkably analogous in the two languages. Noteworthy dissimilarities centre around verb-verb compounding: in Spanish, a somewhat richer semantic typology can be established and the existence of non-nominal outputs seems to be categorically excluded.

The remarkable number of shared traits in the two languages hints at the possible existence of a cross-linguistic set of common core features in the class of coordinate compounds in both Germanic and Romance. Investigating this thoroughly seems to us a worthy avenue of inquiry, but it is left for future research. 


\section{References}

American Heritage dictionary of the English language. 2006. (updated 4th ed.) Boston, MA: Houghton Mifflin. http://education.yahoo.com/reference/dictionary [last accessed on June 9, 2011].

Alvar Ezquerra, M. 1993. La formación de palabras en español. Madrid: Arco/Libros.

Arcodia, G. F. 2010. "Coordinating compounds". Language and Linguistics Compass 4(9). 863873.

Arnaud, P. J. L. 2002. Document de travail sur les noms composés anglais. Unpublished manuscript. Université Lumière Lyon 2.

Bauer, L. 2001. "Compounding". In: Haspelmath, M., E. König, W. Oesterreicher and W. Raible (eds.), Language universals and language typology. Berlin: Walter de Gruyter. Vol. 1, 695707.

Bauer, L. 2008. "Dvandva". Word Structure 1(1). 1-20.

Bauer, L. 2010. "Co-compounds in Germanic". Journal of Germanic Linguistics 22(3). 201-219.

Berg, Th. 2006. "The internal structure of four-noun compounds in English and German". Corpus Linguistics and Linguistic Theory 2(2). 197-231.

Berg, Th. 2009. Structure in language: A dynamic perspective. New York, NY: Routledge.

Bustos Gisbert, E. de. 1986. La composición nominal en español. Salamanca: Ediciones Universidad de Salamanca.

Cook, W. A. 1969. Introduction to tagmemic analysis. New York, NY: Holt, Rinehart and Winston.

Diccionario de la lengua española. 2001. (22nd ed.) Madrid: Espasa Calpe. 
http://buscon.rae.es/drael [last accessed on June 9, 2011].

Fellbaum, C. 2002. "On the semantics of troponymy". In: Green, R., C. A. Bean and S. H. Myaeng (eds.), The semantics of relationships: An interdisciplinary perspective. Dordrecht: Kluwer. $23-34$.

Guevara, E. and S. Scalise. 2009. "Searching for universals in compounding". In: Scalise, S., E. Magni and A. Bisetto (eds.), Universals of language today. Amsterdam: Springer. 101-128.

Jackson, H. and É. Zé Amvela. 2000. Words, meaning and vocabulary: An introduction to modern English lexicology. London: Continuum.

OED = Oxford English dictionary, online edition. http://www.oed.com [last accessed on June 9, 2011].

Paillard, M. 2000. Lexicologie contrastive français-anglais. Formation des mots et construction du sens. Gap: Ophrys.

Rainer, F. and S. Varela. 1992. "Compounding in Spanish". Rivista di Linguistica 4(1). 117-142.

Ralli, A. 2008. "Compound markers and parametric variation". STUF - Language Typology and Universals 61(1). 19-38.

Renner, V. 2006. Les composés coordinatifs en anglais contemporain. $\mathrm{PhD}$ dissertation. Université Lumière Lyon 2. http://tel.archives-ouvertes.fr/docs/00/56/50/46/PDF/Renner2006.pdf [last accessed on June 9, 2011].

Renner, V. 2008. "On the semantics of English coordinate compounds". English Studies 89(5). 606613.

Val Álvaro, J. F. 1999. "La composición". In: Bosque, I. and V. Demonte (eds.), Gramática descriptiva de la lengua española. Madrid: Espasa Calpe. Vol. 3, 4757-4841. 
Coordinate compounding in English and Spanish

Wälchli, B. 2005. Co-compounds and natural coordination. Oxford: Oxford University Press. 